\title{
BENEFITS OF MANGROVE MANAGEMENT FOR PRAWN FISHING AND TIMBER PRODUCTION
}

\author{
Bagus Oktori Sutrisno"1), Slamet Budi Prayitno ${ }^{21}$ \\ 1) Direktorat Kapal Perikanan dan Alat Penangkap Ikan, Direktorat Jenderal Perikanan Tangkap - KKP \\ 2) Jurusan Perikanan, Fakultas Perikanan dan IImu Kelautan - Universitas Diponegoro \\ Received January 10-2013; Received in revised form November 26-2013; Accepted December 03-2013
}

\begin{abstract}
Integrated fisheries resource management is absolutely needed to achieve optimal result and sustainable utilization. This research aims to analyze the benefit of mangrove forest management for prawn fishing and mangrove timber production in Segara Anakan, southern coast of Central Java. The information concerning mangrove coverage changes was achieved from a satellite imagery (Landsat) from 2002 to 2009, while prawn resources stock assessment was analyzed through production surplus method and economic analysis of prawn fishing. The results show that the condition of mangrove ecosystem in Segara Anakan since 2002 to 2009 had been decreasing with average decrease rate of $10,28 \%$ each year which caused to prawn abundance. Utilization of mangrove wood inwhich aged above 20 years would give more benefit to prawn fishing and timber production. The additional economic value for prawn fishing was approximately 3,964 times of cropped woods. Prawn fisheries resource management in Cilacap coastal waters could be done by management of fishing effort and rehabilitation of mangrove forest in Cilacap region and surrounding areas as well especially in Segara Anakan Lagoon.
\end{abstract}

\section{KEYWORDS: Mangrove, prawn, benefit, Segara Anakan, Central Java}

\section{INTRODUCTION}

Capture fish production is determined by both fishing effort and stock availability. Prawn production resulted from fishing effort is defined by total fishing capability of fleets. Fishing activity is considered as the exploit fisheries resources (i.e prawns) within certain boundary (fishing grounds) (Manson and Die, 2001). Stock availability (abundance) depends on biological characters and the condition of the supporting environment (MacKenzie et al., 2003). But, current condition of mangrove forest in Segara Anakan is undergone serious degradation due to illegal cutting and conversion to other uses (Pribadi, 2007). In the other side, sedimentation, and exploitation of natural fish seed fasten the decrease of stock availability of prawn (Adi, 2007). Segara Anakan Lagoon Management Board (BPKSA) reported that in the last 10 years, mangrove area in Segara Anakan Lagoon had been decreased due to high sedimentation happening in this lagoon. This phenomenon have lead the conversion of mangrove area to dry lands. This aggravated condition of mangroves decrease mangrove ecosystem support for prawn resources. Hence, unsuitable environment management would lead to the decrease of fish production (Bayode et al., 2011).

The condition described above figure that fisheries resources management requires an integration of related components. Fisheries resource has specific character, each organism (commodity) has relative different factors affecting its sustainability. Ecological factor (mangrove) and climate (rain fall) playimportant roles. For this reason, relationship among production of prawn fishing, fishing effort, ecological component (mangrove) as well as climate condition (rainfall) is needed to investigate.

\section{MATERIALS AND METHODS}

This research was conducted to obtain information on how far mangrove ecosystem management would affect the prawn fishing and timber cropping efforts in Cilacap area. Variables involved in this research include: a) prawn fishing effort; b) mangrove forest condition; and c) rainfalls as independent variables, while productionof prawn fishing is considered as dependent variable.

Data collection were including previous observation conducted in Cilacap, concerning fish production and related factors mentioned above. Related to research conducted previously, some institutions are considered for additional information regarding this research, such as Department of Forestry and FAO (2002). Data of prawn fishing production were obtained from Marine and Fisheries Service (DKP) of Cilacap Regency, regarding time serial dataof fish landing from 2002 to 2009. Primary data collection was conductedthrough observation and direct interview to local fishermen concerning the factors related to prawn fishing activity. 
Condition of mangrove forest was regarded asthe extent of mangrove coverage in Segara Anakan Lagoon area. Information of mangrove extent was analysed from primary and secondary data. Primary data were collected through a satellite imagery interpretation. Landsat imagery was used to estimate the extent of mangrove forest in pertinent years. Image data used included the image data from 2002 to 2009. that were downloaded from glovis.usgs.gov. Analysis method was supervised classification to extract the information of coastal land coverage regarding the mangrove ecosystem (forestry) extent.

Stock assessment of prawn resources was based on surplus production method by Schaefer (1954). Stock assessment included: 1) fishing gear standardization; 2) fishing effort standardization; and 3) biophysic model. Modification of the model was conducted to deliver mangrove extent as the additional factor effecting fish production. Hence, economic analysis was modified as well. Analysis technique conducted was multiple regression analysis.
Economic analysis of prawn fishing was conductedbased on average price of jerbung prawn and dogol prawn. Hence, total benefit of prawn fishing would be:

$$
\delta=\left\{\left(a_{1} X+a_{2} X^{2}+a_{3} M X\right) * p\right\}-c^{*} X
$$

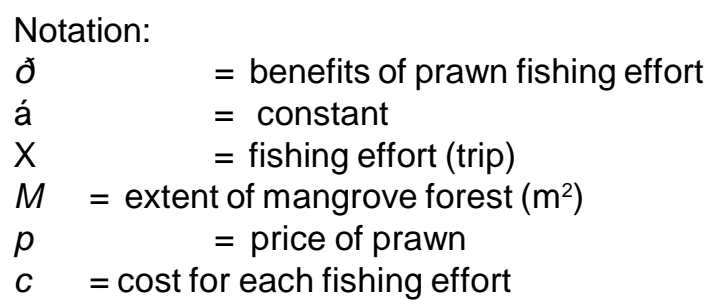

\section{RESULTS AND DISCUSSION}

Analysis from primary and secondary data resulted the fishing effort, extent of mangrove coverage and prawn production from 2002 to 2009 as tabulated in Table 1.

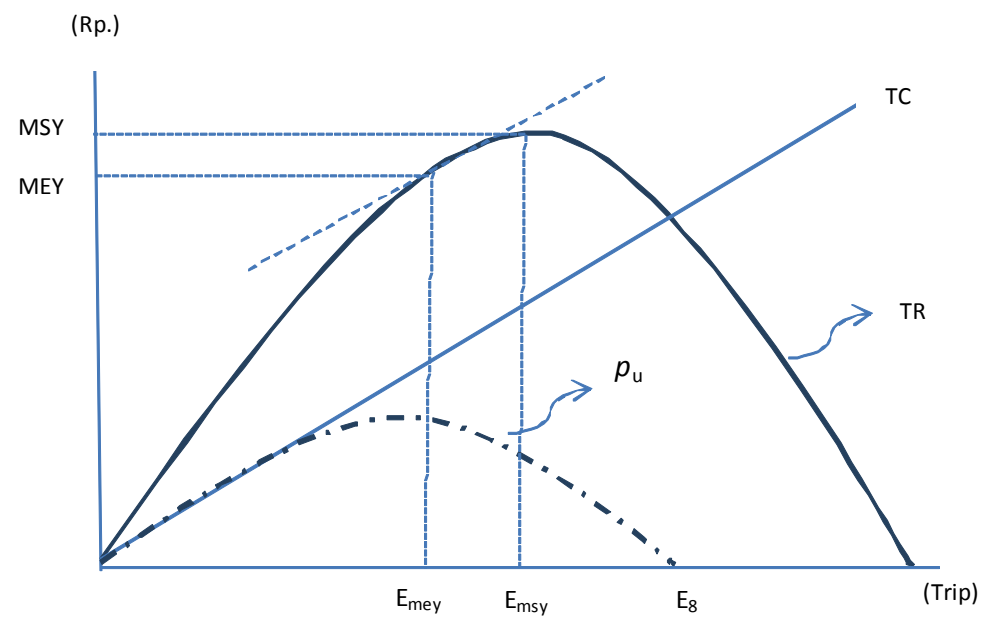

Figure 1. Curve of MSY and MEY.

Table 1. Fishing effort, mangrove coverage and prawnproduction (Dogol and Jerbung) in southern coast of Cilacap in $2002-2009$

\begin{tabular}{|c|c|c|c|c|c|}
\hline \multirow{2}{*}{\multicolumn{2}{|c|}{ Year }} & \multirow{2}{*}{$\begin{array}{l}\text { Fishing effort } \\
\text { (trip) }\end{array}$} & \multirow{2}{*}{$\begin{array}{l}\text { Mangrove coverage } \\
\text { (ha) }\end{array}$} & \multicolumn{2}{|c|}{ Prawn production (ton) } \\
\hline & & & & Dogol prawn & Jerbung prawn \\
\hline - & 2002 & - 8,897 & $9,163.19$ & 500.04 & 447.37 \\
\hline & 2003 & 9,226 & $8,433.00$ & 508.58 & 461.55 \\
\hline & 2004 & 8,200 & $7,764.00$ & 400.74 & 432.84 \\
\hline & 2005 & 9,091 & $7,252.72$ & 472.77 & 507.53 \\
\hline & 2006 & 10,093 & $6,213.80$ & 471.22 & 412.17 \\
\hline & 2007 & 13,253 & $5,767.16$ & 292.90 & 344.67 \\
\hline & 2008 & 11,202 & $4,987.00$ & 279.67 & 282.33 \\
\hline & 2009 & 5,388 & $4,267.13$ & 191.16 & 201.67 \\
\hline
\end{tabular}


The prawn price used in analysis of fishing effort was average auction price of dogol and jerbung prawns which was Rp. 64.352,-/kg. Costs in prawn fishing effort by trammel net included the operational costs (gasoline, oil, ice, food and fishing crew), maintenance cost (kasko, machine and fishing gear) and other costs (fishing licence, retribution and unloading). Average fishing costs were calculated from each in peak, middle and famine seasons. Average fishing cost by trammel net on each boat size was Rp. $147,323.514$, Rp. $1,702,024.534$, and Rp. $5,088,039.417$ for boats with size of $<10 \mathrm{GT}, 10-20$ GT 20 - 30 GT, respectively.

Mangrove woods were cropped and commercialized by local people, usually used as raw material for charcoal, building and firewood. Charcoal factory bought mangrove woods from local people for Rp. $70.000,-/ \mathrm{m}^{3}$. Within one period of mangrove cropping, each person only needed a boat worthed Rp. 3.500.000,- and a piece of cleaver and would produce $1,5 \mathrm{~m}^{3}$ of mangrove woods. The amount would be achieved by cropping mangrove woods within the area of $16 \mathrm{~m}^{2}$. Unfortunately, commercial mangrove utilization was causing a damaged area extended to $60 \mathrm{~m}^{2}$.

Multiple regression analysis concerning surplus production model by Schaefer and considering mangrove area coverage formulated the model for prawn production as: $\mathrm{Q}=56,160 \mathrm{X}-0,00529292 \mathrm{X}^{2}+$ $0,0116885 \mathrm{MX}$. Hence, potential prawn production from 2002 to 2009 could be estimated as presented in Table 2.

If mangrove coverage is maintained or even extended by a reboization, it would affect to the potentialof prawn resources and production. The simulation shows the probabilities of mangrove management by maintaining or extending mangrove coverage would affect the variation of prawn fishing production as shown in Table 3.

Table 2. Fishingeffort, mangrove coverage and potential production of Prawn in southern coast of Cilacap

\begin{tabular}{cccc}
\hline Year & Fishing effort(trip) & Mangrove coverage (ha) & $\begin{array}{c}\text { Production } \\
\text { (tons) }\end{array}$ \\
\hline 2002 & 8,897 & $9,163.19$ & $1,004.21$ \\
2003 & 9,226 & $8,433.00$ & 948.94 \\
2004 & 8,200 & $7,764.00$ & 825.80 \\
2005 & 9,091 & $7,252.72$ & 820.05 \\
2006 & 10,093 & $6,213.80$ & 738.11 \\
2007 & 13,253 & $5,767.16$ & 680.50 \\
2008 & 11,202 & $4,987.00$ & 597.79 \\
2009 & 5,388 & $4,267.13$ & 409.36 \\
\hline
\end{tabular}

Figure 2 shows that at the same level of fishing effort, the more mangrove extent is maintained, the more potential yield of prawn is achieved. The simulation indicates when fishing effort is at 6,000 trips per year, potential yield of $496,070 \mathrm{~kg}$ of prawn is achieved when mangrove extent is maintained at 5,000 ha. At the same level of fishing effort $(6,000$ trips per year), potential yield of $567,201 \mathrm{~kg}$ of prawn is achieved when mangrove extent is maintained at 6,000 ha. Yet, potential yield of prawn decreases to $426,939 \mathrm{~kg}$ when mangrove extent is maintained at 4,000 ha.

Mangrove growth rate pattern is logarithmic with relative long growth period ( $15-35$ years). Colaborative research conducted by Department of Forestry and Plantation with JICA (1999) showed that mangrove growth differs into 2 types including high growth and low growth as shown in Table 4 and Table 5.
High growth occurred on land area where mangrove would not achieve pressure which inhibit mangrove growth and natural reproduction process or contain factors supporting its growth to be faster. While the causalities of low growth of mangrove are not obviously revealed. But, based on field observation and measurement in permanent plot, it is known that mangrove forest which grow within islands and sandy beaches are the main factors wich limit mangrove growth and natural reproduction.

Canopy (leaves and litter coverage) of mangrove would directly affect the abundance of prawn while mangrove has reached the age of 5 years and average height of 3 meters. Based on the assumption wether prawn abundance is related to mangrove growth rate, and wether Segara Anakan is dominated by delta, it is concluded that mangrove growth within the study area is rapid growth mangrove. 
Table 3. Simulation on the potential of prawnfishing production (Dogol and Jerbung) at certain mangrove coverage along southern coast of Cilacap.

\begin{tabular}{ccccccc}
\hline $\begin{array}{c}\text { Fishing } \\
\text { effort }\end{array}$ & 9,000 & $\mathbf{8 , 0 0 0}$ & $\mathbf{7 , 0 0 0}$ & $\mathbf{6 , 0 0 0}$ & $\mathbf{5 , 0 0 0}$ & $\mathbf{4 , 0 0 0}$ \\
\hline 1,000 & $156,059.00$ & $144,371.00$ & $132,683.00$ & $120,995.00$ & $109,307.00$ & $97,619.00$ \\
2,000 & $301,532.00$ & $278,156.00$ & $254,780.00$ & $231,404.00$ & $208,028.00$ & $184,652.00$ \\
3,000 & $436,419.00$ & $401,355.00$ & $366,291.00$ & $331,227.00$ & $296,163.00$ & $261,099.00$ \\
4,000 & $560,720.00$ & $513,968.00$ & $467,216.00$ & $420,464.00$ & $373,712.00$ & $326,960.00$ \\
5,000 & $674,435.00$ & $615,995.00$ & $557,555.00$ & $499,115.00$ & $440,675.00$ & $382,235.00$ \\
6,000 & $777,564.00$ & $707,436.00$ & $637,308.00$ & $567,180.00$ & $497,052.00$ & $426,924.00$ \\
7,000 & $870,107.00$ & $788,291.00$ & $706,475.00$ & $624,659.00$ & $542,843.00$ & $461,027.00$ \\
8,000 & $952,064.00$ & $858,560.00$ & $765,056.00$ & $671,552.00$ & $578,048.00$ & $484,544.00$ \\
9,000 & $1,023,435.00$ & $918,243.00$ & $813,051.00$ & $707,859.00$ & $602,667.00$ & $497,475.00$ \\
10,000 & $1,084,220.00$ & $967,340.00$ & $850,460.00$ & $733,580.00$ & $616,700.00$ & $499,820.00$ \\
11,000 & $1,134,419.00$ & $1,005,851.00$ & $877,283.00$ & $748,715.00$ & $620,147.00$ & $491,579.00$ \\
12,000 & $1,174,032.00$ & $1,033,776.00$ & $893,520.00$ & $753,264.00$ & $613,008.00$ & $472,752.00$ \\
13,000 & $1,203,059.00$ & $1,051,115.00$ & $899,171.00$ & $747,227.00$ & $595,283.00$ & $443,339.00$ \\
14,000 & $1,221,500.00$ & $1,057,868.00$ & $894,236.00$ & $730,604.00$ & $566,972.00$ & $403,340.00$ \\
15,000 & $1,229,355.00$ & $1,054,035.00$ & $878,715.00$ & $703,395.00$ & $528,075.00$ & $352,755.00$ \\
16,000 & $1,226,624.00$ & $1,039,616.00$ & $852,608.00$ & $665,600.00$ & $478,592.00$ & $291,584.00$ \\
17,000 & $1,213,307.00$ & $1,014,611.00$ & $815,915.00$ & $617,219.00$ & $418,523.00$ & $219,827.00$ \\
18,000 & $1,189,404.00$ & $979,020.00$ & $768,636.00$ & $558,252.00$ & $347,868.00$ & $137,484.00$ \\
19,000 & $1,154,915.00$ & $932,843.00$ & $710,771.00$ & $488,699.00$ & $266,627.00$ & $44,555.00$ \\
\hline
\end{tabular}

Note: prawn production unit $=$ tons

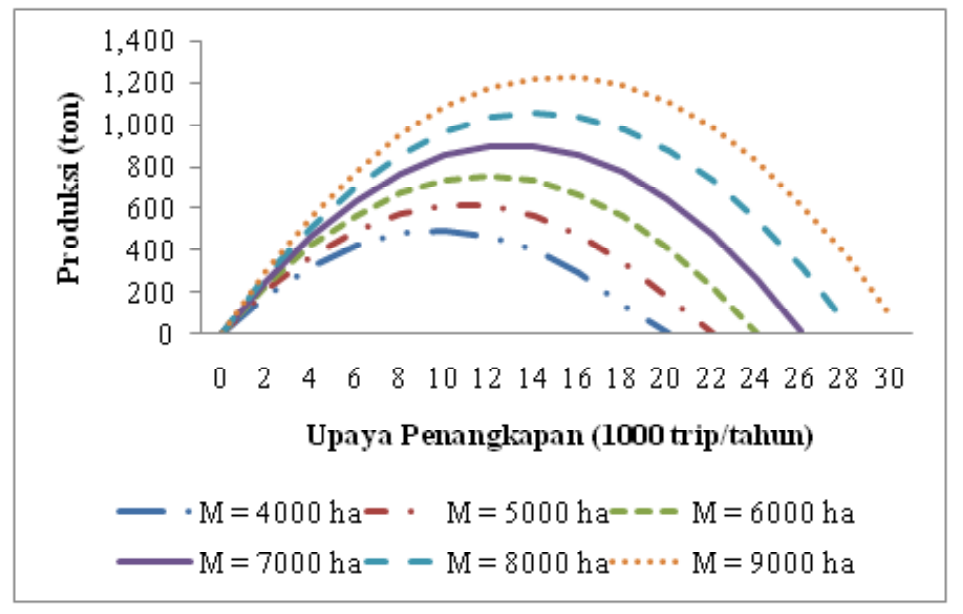

Figure. 2. Relation of fishing effort $(X)$ and mangrove extent $(M)$ to prawn production in Cilacap waters.

Table 4. Mangrove growth of Rhyzophora apiculata on high growth plot (JICA, 1999)

\begin{tabular}{lcccccc}
\hline \multicolumn{1}{c}{ Age (Years) } & $\mathbf{1 0}$ & $\mathbf{1 5}$ & $\mathbf{2 0}$ & $\mathbf{2 5}$ & $\mathbf{3 0}$ & $\mathbf{3 5}$ \\
\hline Average Height $(\mathrm{m})$ & 12.41 & 16.11 & 19.54 & 22.30 & 24.32 & 25.71 \\
Tree Frequency/Ha & 4,983 & 2,516 & 1,644 & 1,200 & 1,066 & 9,600 \\
Stand Volume $\left(\mathrm{m}^{3 / / h a}\right)$ & 105.86 & 135.36 & 186.21 & 243.20 & 295.13 & 336.61 \\
Effective Stand Volume $\left(\mathrm{m}^{3 / \mathrm{ha}}\right)$ & 63.52 & 81.21 & 111.72 & 145.92 & 177.08 & 201.97 \\
\hline
\end{tabular}


Table 5. Mangrove growth of Rhyzophora apiculata on low growth plot (JICA, 1999)

\begin{tabular}{lllllll}
\hline \multicolumn{1}{c}{ Age (Years) } & \multicolumn{10}{c}{$\mathbf{1 0}$} & $\mathbf{1 5}$ & $\mathbf{2 0}$ & $\mathbf{2 5}$ & $\mathbf{3 0}$ & $\mathbf{3 5}$ \\
\hline Average Height $(\mathrm{m})$ & 3.84 & 7.10 & 9.63 & 11.23 & 12.12 & 12.59 \\
Tree Frequency/ha & 6.723 & 5.565 & 5.063 & 4.828 & 4.715 & 4.659 \\
Stand Volume $\left(\mathrm{m}^{3} / \mathrm{ha}\right)$ & 7.94 & 40.33 & 88.57 & 130.17 & 157.45 & 173.07 \\
Effective Stand Volume $\left(\mathrm{m}^{3} / \mathrm{ha}\right)$ & 4.76 & 24.24 & 53.14 & 78.10 & 94.47 & 103.84 \\
\hline
\end{tabular}

Simulation on the direct benefit of mangrove plantation within 100 ha coverage each year and harvesting would be done after mangrove ages reaches20 years shows the importance of good mangrove management. After first 3 to 20 years, the benefit would only be achieved from prawn fishing which would be continuously raising and reach a production of $370.44 \mathrm{~kg}$ of prawn with worthed $\mathrm{Rp}$. $23,832,868$ In $4^{\text {th }}$ to $20^{\text {th }}$ year prawn production would achieve $56,677.45 \mathrm{~kg}$ worthed Rp.36,463,428,736,-. Then, from $21^{\text {st }}$ year, instead of prawn fishing, additional benefit would be achieved from mangrove harvesting. Mangrove cropping would give extra benefit of 11,172 $\mathrm{m}^{3}$ for 100 ha worthed Rp.782,040,000,-. This additional revenue analysis is simulated in Figure 3.

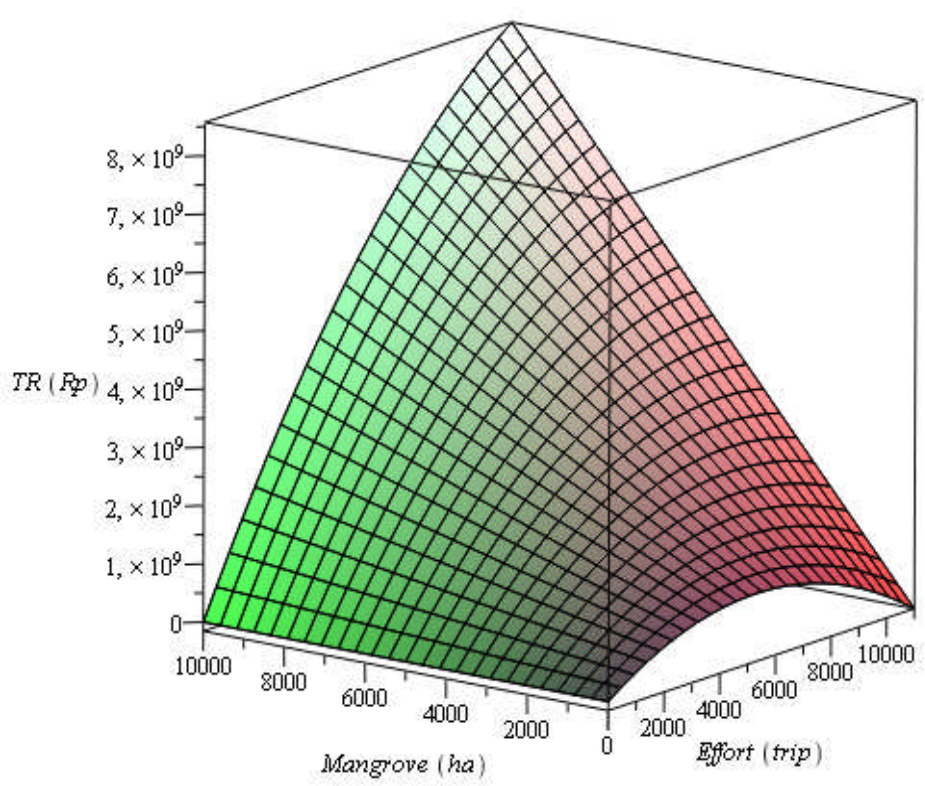

Figure. 3. Relation of fishing effort and mangrove extent to total revenue of prawn production in Cilacap waters.

By the assumption of mangrove coverage could be maintained in $4,267.13$ ha, the analysis shows that sustainable yeld of prawn fishing in Cilacap would be $531,101.5 \mathrm{~kg} / \mathrm{yr}$. By this potential, prawn fishing in Cilacap had been overfished for several times.

Regression analysis on the relation of fishing effort, mangrove coverage and rainfall to CPUE shows that fishing effort and mangrove coverage simultanuously affected the production of prawn, while rainfall did not give significant effect. Regression analysis of fishing effort and mangrove coverage to CPUE resulted the formula as $Q=56,16-0,005293 X+0,016885 \mathrm{M}$.
The formula shows that the fishing effort gave a negative effect to prawn production for each fishing trip while mangrove coverage had possitive effect. Each additional fishing trip would cause to the decrease of CPUE as $0.005293 \mathrm{~kg}$ while mangrove coverage extension woul raise prawn production to $0.016885 \mathrm{~kg}$.

Mangrove forest management by plantation of 100 ha/yr and harvesting after 20 years would give additional revenue to prawn fishing and timber production. At 20 first year, benefit of timber production would not be achieved, but prawn fishing does achieve the benefit. Started from the 21st year, additional 
revenue from prawn fishing would be $R p$. 3,099,464,426 which means 3.964 times of mangrove cropping which would be Rp. 782,040,000/yr. The role of mangrove for fisheries production had been well known such as prodiving nursery ground and protection for fishes, crabs and prawns (Sarker et al., 2010). Hence, maintained mangrove ecosystem would provide possitive feedback to fisheries resources, and additional extent of mangrove should provide better sustainability of fisheries utilization.

As well as temperature, rainfall is one of climatic factors widely expected to have significant relation with fisheries production. Several researches showed there were no significant correlation between rainfall and fisheries productivity such as CPUE or landings (Ayub, 2010). Hoguane et al. (2012) mentioned that rainfall and fisheries did not have direct relation. Rainfall plays the role in freshwater supply, decrease of temperature, and distribution of nutrient as well.

Fisheries management regarding utilization of mangrove should be conducted to maintan the sustainability of fisheries productivity and mangrove as well. Beitl (2012) explain that mangrove management should involve local public regarding community participation. Local rule concerning the implementation of sustainable harvest should be established either.

\section{CONCLUSIONS}

Mangrove ecosystem in Southern Coast of Central Java (Cilacap) was found in poor condition, this is shown by decrease of mangrove coverage from $9,163.19$ ha in 2002 to $4,267.13$ ha in 2009 , with average about $10.2803 \% / y r$. This is unexpected condition might influence the prawn fishing production.

Beside of mangrove coverage, prawn fishing production, including dogol and jerbung prawns significantly is well influenced by fishing effort that has negative effect to the prawn production. Every additional effort would decrease the CPUE while mangrove coverage has have possitive it which means that additional mangrove extent would raise the prawn abundance. Therefore, the reboization activity might be expected to enhance to the prawn production.

The annual reboization of mangrove by plantation in Segara Anakan and harvesting after 20 years would give additional revenue to both prawn fishing and timber production. However, the additional revenue for prawn fishing would be estimated for 3,964 times of harvested woods.
The curent work may suggest the prawn resources management in Cilacap should consider a controlling of the fishing effort and a management measure such as a rehabilitation of mangrove forest in Cilacap region, especially within Segara Anakan Lagoon area. Thise effort should be at least to keep the mangrove coverage of 4.267,13 ha as recorded in 2009.

\section{REFERENCES}

Ayub, Z. 2010. Effect of Temperature and Rainfall as a Component of Climate Change on Fish and Shrimp Catch in Pakistan. The Journal of Transdisciplinary Environmental Studies 9(1): 1 9.

Bayode, O.J.A., E.A. Adewunmi \& S. Odunwole. 2011. Environmental Implications of Oil Exploration and Exploitation in the Coastal Region of Ondo State, Nigeria: A Regional Planning Appraisal. Journal of Geography and Regional Planning. 4(3): 110-121.

Beitl, C.M. 2012. Shifting Policies, Access, and the Tragedy of Enclosures in Ecuadorian Mangrove Fisheries: Towards A Political Ecology of the Commons. Journal of Political Ecology 19: $94-$ 113.

Department of Forestry and Food and Agriculture Organization. 2002. Situation and Outlook of the Forestry Sector in Indonesia 2. Forest Resource Base. Dephut dan FAO. Jakarta.

Hoguane, A.M., E.L. Cuamba \& T. Gammelsrd. 2012. Influence of rainfall on tropical coastal artisanal fisheries - a case study of Northern Mozambique. Journal of Integrated Coastal Zone Management 12(4): $477-482$.

Manson, F.J. \& D.J. Die. 2001. Incorporating Commercial Fishery Information Into the Design of Marine Protected Areas. Ocean and Coastal Management 44: 517-530.

MacKenzie, B.R., R.A. Myers \& K.G. Bowen. 2003. Spawner-recruit Relationships and Fish Stock Carrying Capacity in Aquatic Ecosystems. Marine Ecology Progress Series 248: 209-220.

Pribadi, R. 2007. Mangrove Vegetation of Segara Anakan Cilacap, Java, Indonesia: Structure Composition, Litter-Fall Production And Decomposition. In Yuwono et al. (eds): Synopsis of Ecological and Socio-Economic Aspects of Tropical Coastal Ecosystem with Special 
Benefits of Mangrove Management for Prawn Fishing and Timber Production (Sutrisno, B.O \& S. B Prayitno)

Reference to Segara Anakan. Research Institute University of Jenderal Soedirman Purwokerto: 1 10.
Sarker, S., K.C. Kuri, M.S.M. Chowdhury \& M.T. Rahman. 2010. Mangrove: A Livelihood Option for Coastal Community of Bangladesh. Bangladesh Research Publication Journal3(4): 1187- 1192. 